\title{
Intestinal pseudo-obstruction in patients with amyloidosis: clinicopathologic differences between chemical types of amyloid protein
}

\author{
S Tada, M Iida, T Yao, T Kitamoto, T Yao, M Fujishima
}

\begin{abstract}
A clinicopathologic study was made of 16 patients with amyloidosis and with clinical signs of intestinal pseudo-obstruction. Amyloid deposits in the small intestine were proved in all cases by endoscopic or intraoperative biopsies, and immunohistochemical study identified the chemical types of amyloid protein: amyloid $A$ protein (AA) in 13 cases, light chain protein ( $A L)$ in two, and $\beta_{2}$-microglobulin (AH) in one. Clinically, an acute self limiting obstructive condition was evident in 13 cases with $\mathbf{A A}$, and 12 of them returned to normal bowel function after receiving total parenteral nutrition. Two cases with $A L$ and one with AH presented chronic, intermittent, obstructive symptoms, and medical treatment, including total parenteral nutrition, was ineffective with no recovery of intestinal propulsion. Pathological examination of the necropsy specimens in seven cases showed considerable differences in the preferential sites of gastrointestinal deposits between the chemical types of amyloid; extensive infiltration and replacement of the muscularis propria by amyloid deposits throughout the gastrointestinal tract, especially the small intestine, were found in the AL and the AH cases, while amyloid deposits in the myenteric plexus without appreciable muscle infiltration were shown in the AA cases. These results show that intestinal pseudo-obstruction in patients with amyloidosis is caused by either myopathy or neuropathy, and that chemical types of amyloid may determine which of the two factors has the dominant affect on the bowel function.
\end{abstract}

(Gut 1993; 34: 1412-1417)

Departments of Internal Medicine II, Pathology II, and Neuropathology, Faculty of Medicine, Kyushu University, Fukuoka, Japan

S Tada

M Iida

T Yao

T Kitamoto

M Fujishima

Department of Gastroenterology, Fukuoka University, Chikushi Hospital, Fukuoka, Japan T Yao

Correspondence to: Dr S Tada, Second Department of Interna Medicine, Faculty of Medicine, Kyushu University, Maidashi 3-1-1, Higashi-ku, Fukuoka 812, Japan.

Accepted for publication 16 February 1993
Intestinal pseudo-obstruction is a clinical syndrome characterised by symptoms and signs of intestinal obstruction despite the absence of mechanical blockage of the intestinal lumen. ${ }^{1-3}$ Systemic amyloidosis often affects the gastrointestinal tract $^{45}$ and may result in this condition. ${ }^{6-8}$ It is unclear, however, whether the impaired gastrointestinal motility is secondary to the effects of amyloid on the smooth muscle or on the autonomic nervous system, because there have been few reports assessing the clinicopathologic features in a considerable number of amyloidosis patients with intestinal pseudoobstruction.

Recently, biochemical analyses have shown that several different types of amyloid fibril protein exist in systemic amyloidosis. Light chain protein (AL) amyloid, which is of immunoglobulin origin, is found in primary or myeloma-associated amyloidosis. ${ }^{9}{ }^{10}$ Secondary amyloidosis associated with chronic inflammatory diseases consists of amyloid A (AA) protein. ${ }^{112} \mathrm{AH}$ amyloid consisting of $\beta_{2}$-microglobulin is found in patients receiving longterm haemodialysis..$^{1314}$ It is now widely recognised that amyloidosis, rather than being a single disease entity, represents a group of diseases that have in common characteristic microscopic staining properties and electron microscopic fibrillar configuration. ${ }^{\text {s }}$ Correlations between the chemical types, however, of amyloid and histological or clinical features in amyloidosis patients with intestinal pseudo-obstruction have never been determined.

The aims of this study were: (a) to explore the distinguishing clinical characteristics between the patients with three types of amyloidosis who presented with clinical signs of intestinal pseudoobstruction, and (b) to examine the relations between the clinical features and pathological findings.

\section{Methods}

\section{PATIENTS}

Between 1978 and 1992, we saw 17 patients with amyloidosis who presented with clinical signs of intestinal obstruction. Of these, 11 patients initially came to the hospital complaining of abdominal distension, cramping, anorexia, vomiting, constipation or diarrhoea, and we found six in whom such clinical signs developed during the follow up of illness. The abdominal plain films of these patients showed abnormal accumulation of gastrointestinal gas, dilated loops of the small and large bowel, with occasional air-fluid values. Two patients had emergency laparotomy and no mechanical obstruction was found. In the other 14 patients, barium studies of the small and large intestine did not show any mechanical obstruction. The remaining patient showed a large mass in the jejunum, which was histopathologically diagnosed as an amyloid tumor. Excluding this exceptional case, we examined 16 patients showing clinical signs of intestinal pseudo-obstruction.

\section{IDENTIFICATION OF AMYLOID PROTEIN}

One patient had primary amyloidosis, two had myeloma associated amyloidosis, one had haemodialysis associated amyloidosis, and 12 had secondary amyloidosis (rheumatoid arthritis in eight, ankylosing spondylitis in one, adult Still's disease in one, polymyositis in one, and 
TABLE I Summary of the clinical data from amyloidosis patients with intestinal pseudo-obstruction

\begin{tabular}{|c|c|c|c|c|c|c|c|}
\hline $\begin{array}{l}\text { Case } \\
\text { no }\end{array}$ & $\begin{array}{l}\text { Age (y) } \\
\text { and sex }\end{array}$ & $\begin{array}{l}\text { Underlying } \\
\text { disease }\end{array}$ & $\begin{array}{l}\text { Chemical } \\
\text { types of } \\
\text { amyloid }\end{array}$ & $\begin{array}{l}\text { Onset of obstructive } \\
\text { symptoms (duration) }\end{array}$ & Treatment & $\begin{array}{l}\text { Ileus } \\
\text { reversibility }\end{array}$ & $\begin{array}{l}\text { Interval between } \\
\text { the diagnosis and } \\
\text { death or survival }\end{array}$ \\
\hline $\begin{array}{l}1 \\
2 \\
3\end{array}$ & $\begin{array}{l}77 M \\
51 F \\
42 M\end{array}$ & $\begin{array}{l}\text { Multiple myeloma } \\
\text { Multiple myeloma } \\
\text { Chronic haemodialysis }\end{array}$ & $\begin{array}{l}\text { AL } \\
\text { AL } \\
\text { AH }\end{array}$ & $\begin{array}{l}\text { Chronic (2 y } 3 \mathrm{mth}) \\
\text { Chronic (2 y) } \\
\text { Chronic (2 y } 10 \mathrm{mth})\end{array}$ & $\begin{array}{l}\text { TPN, Ch, M } \\
\text { TPN, Ch, M } \\
\text { M-A tube, TPN, } \\
\text { Ch, M, Ci }\end{array}$ & $\begin{array}{l}\text { Irreversible } \\
\text { Irreversible } \\
\text { Irreversible }\end{array}$ & $\begin{array}{l}1 \mathrm{mth} \text { died } \\
2 \mathrm{mth} \text { died } \\
2 \text { y } 3 \text { mth died }\end{array}$ \\
\hline $\begin{array}{r}4 \\
5 \\
6 \\
7 \\
8 \\
9 \\
10 \\
11 \\
12 \\
13 \\
14 \\
15 \\
16\end{array}$ & $\begin{array}{l}65 \mathrm{M} \\
60 \mathrm{~F} \\
42 \mathrm{~F} \\
24 \mathrm{~F} \\
62 \mathrm{~F} \\
52 \mathrm{M} \\
47 \mathrm{~F} \\
44 \mathrm{M} \\
42 \mathrm{M} \\
36 \mathrm{M} \\
34 \mathrm{~F} \\
30 \mathrm{~F} \\
23 \mathrm{M}\end{array}$ & $\begin{array}{l}\text { Rheumatoid arthritis } \\
\text { Rheumatoid arthritis } \\
\text { Rheumatoid arthritis } \\
\text { Polymyositis } \\
\text { Rheumatoid arthritis } \\
\text { Ankylosing spondylitis } \\
\text { Rheumatoid arthritis } \\
\text { Rheumatoid arthritis } \\
\text { Adult Still's disease } \\
\text { Rheumatoid arthritis } \\
\text { Rheumatoid arthritis } \\
\text { None } \\
\text { Crohn's disease }\end{array}$ & $\begin{array}{l}\text { AA } \\
\text { AA } \\
\text { AA } \\
\text { AA } \\
\text { AA } \\
\text { AA } \\
\text { AA } \\
\text { AA } \\
\text { AA } \\
\text { AA } \\
\text { AA } \\
\text { AA } \\
\text { AA }\end{array}$ & $\begin{array}{l}\text { Acute }(3 \mathrm{wk}) \\
\text { Acute }(6 \mathrm{wk}) \\
\text { Acute }(4 \mathrm{wk}) \\
\text { Subacute }(10 \mathrm{wk}) \\
\text { Acute }(8 \mathrm{wk}) \\
\text { Acute }(4 \mathrm{wk}) \\
\text { Acute }(5 \mathrm{wk}) \\
\text { Acute }(3 \mathrm{wk}) \\
\text { Subacute }(14 \mathrm{wk}) \\
\text { Acute }(8 \mathrm{wk}) \\
\text { Acute }(4 \mathrm{wk}) \\
\text { Subacute }(10 \mathrm{wk}) \\
\text { Acute }(9 \mathrm{wk})\end{array}$ & $\begin{array}{l}\text { TPN, Ci, M } \\
\text { TPN, M } \\
\text { TPN } \\
\text { TPN, P } \\
\text { TPN } \\
\text { TPN, M } \\
\text { TPN } \\
\text { TPN } \\
\text { M-A tube, TPN } \\
\text { TPN } \\
\text { TPN } \\
\text { TPN, M } \\
\text { TPN, P }\end{array}$ & $\begin{array}{l}\star \\
\text { Reversible } \\
\text { Reversible } \\
\text { Reversible } \\
\text { Reversible } \\
\text { Reversible } \\
\text { Reversible } \\
\text { Reversible } \\
\text { Reversible } \\
\text { Reversible } \\
\text { Reversible } \\
\text { Reversible } \\
\text { Reversible }\end{array}$ & $\begin{array}{l}3 \text { wk died } \\
2 \text { mth died } \\
3 \text { y } 1 \mathrm{mth} \text { died } \\
5 \text { y } 8 \text { mth died } \\
4 \text { y } 2 \mathrm{mth} \text { alive } \\
8 \text { y } 10 \mathrm{mth} \text { alive } \\
2 \text { y } 5 \mathrm{mth} \text { alive } \\
1 \text { y } 11 \mathrm{mth} \text { died } \\
6 \text { y } 10 \mathrm{mth} \text { alive } \\
2 \text { y } 4 \mathrm{mth} \text { alive } \\
4 \text { y } 3 \text { mth alive } \\
10 \text { y } 7 \text { mth alive } \\
6 \text { y } 6 \text { mth alive }\end{array}$ \\
\hline
\end{tabular}

TPN = total parenteral nutrition, $\mathrm{Ch}=$ cholinergic agents, $\mathrm{M}=$ metoclopramide, $\mathrm{M}-\mathrm{A}=\mathrm{Miller}-\mathrm{Abbott}$ tube, $\mathrm{Ci}=$ cisapride

$P=$ prednisolone. $A A=$ anyloid $A$ protein, $A L=$ light chain protein, $A H=\beta_{2}-$ microglobulin protein.

*We could not evaluate the ileus reversibility because this patient died of renal failure and sepsis shortly after admission to hospital.

Crohn's disease in one). Using a long duodenofibrescope, ${ }^{16}$ endoscopic biopsy specimens of the jejunum showed amyloid deposits in 15 patients. In the remaining patient, amyloid deposits of the jejunum were confirmed by intraoperative biopsy specimens. Using these specimens, chemical types of amyloid protein were identified by the avidin-biotin complex (ABC) method using anti- $\mathrm{AA}^{17}$, anti- $\boldsymbol{\beta}_{2}$-microglobulin (1:500, Dako), and anti-prealbumin (1:500, Dako) antibodies. For a comparative evaluation of amyload protein, potassium permanganate $\left(\mathrm{KMnO}_{4}\right)$ treatment was performed before staining with Congo red. ${ }^{18} \mathrm{AA}$ protein was identified by positive staining with anti-AA antibody and sensitivity to $\mathrm{KMnO}_{4}$ reaction, while $A L$ protein failed to stain with anti-AA, anti- $\beta_{2}$-micro-

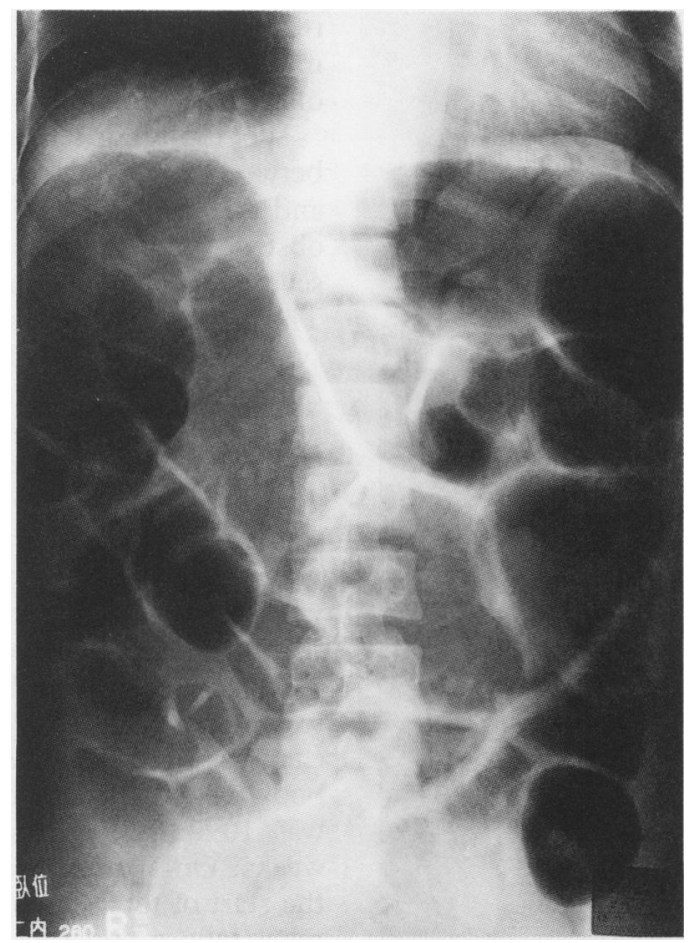

Figure 1: Plain abdominal radiograph of patient with $\beta_{2^{-}}$ microglobulin protein $(\mathrm{AH})$ amyloidosis (case 3 ) showed gaseous dilatation of the small and large intestine. The gaseous dilatation of the bowel was consistently seen until the patient died of cardiac failure. globulin, and anti-prealbumin antibodies, and was resistant to $\mathrm{KMnO}_{4}$ reaction. $\mathrm{AH}$ protein was shown by positive staining with anti- $\beta_{2^{-}}$ microglobulin antibody and by negative staining with other antibodies.

\section{NECROPSY EXAMINATION}

Of the 16 patients, three died at the time of their first hospital admission and five died subsequently. Postmortem examination was carried out in seven patients, and the gastrointestinal tract was fixed in $10 \%$ neutral buffered formalin. From each of the oesophagus (lower third), stomach (fundus and antrum), duodenum (second portion), jejunum (within $50 \mathrm{~cm}$ from the Treitz ligament), ileum (within $50 \mathrm{~cm}$ from

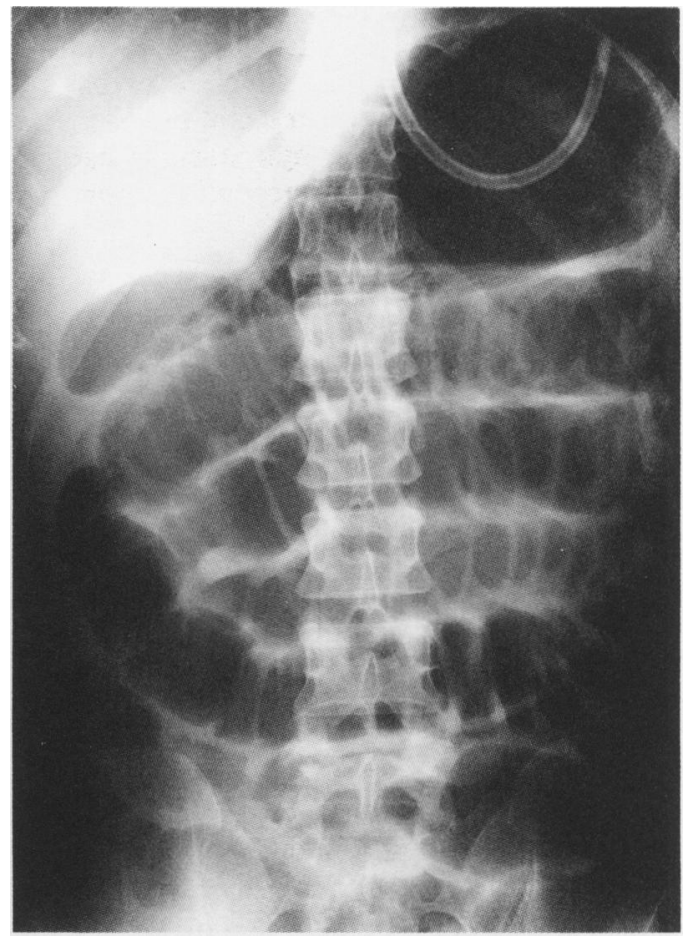

Figure 2: Plain abdominal radiograph of patient with anyloid A protein ( $A A$ ) amyloidosis (case 9) showed gaseous distension of the stomach and small intestine. This finding disappeared after total parenteral nutrition treatment, and there was no recurrence during the follow up period. 
TABLE II Histological findings of the small intestine in seven necropsy cases with intestinal pseudo-obstruction

\begin{tabular}{|c|c|c|c|c|c|c|}
\hline \multirow[b]{2}{*}{ Case no } & \multirow{2}{*}{$\begin{array}{l}\text { Chemical } \\
\text { types of } \\
\text { amyloid }\end{array}$} & \multicolumn{2}{|c|}{ Muscularis propria } & \multicolumn{2}{|c|}{ Myenteric plexuses } & \multirow{2}{*}{$\frac{\text { Vessels }}{\begin{array}{l}\text { Amyloid } \\
\text { deposits }\end{array}}$} \\
\hline & & $\begin{array}{l}\text { Amyloid } \\
\text { deposits }\end{array}$ & $\begin{array}{l}\text { Muscle } \\
\text { replacement }\end{array}$ & $\begin{array}{l}\text { Amyloid } \\
\text { deposits }\end{array}$ & $\begin{array}{l}\text { Degeneration } \\
\text { and reduction }\end{array}$ & \\
\hline $\begin{array}{l}1 \\
2 \\
3 \\
4 \\
5 \\
6 \\
7\end{array}$ & $\begin{array}{l}\mathrm{AL} \\
\mathrm{AL} \\
\mathrm{AH} \\
\mathrm{AA} \\
\mathrm{AA} \\
\mathrm{AA} \\
\mathrm{AA}\end{array}$ & $\begin{array}{l}+++ \\
++ \text { to }+++ \\
+++ \\
- \\
- \text { to }+ \\
+ \\
+\end{array}$ & $\begin{array}{l}+++ \\
++ \text { to }+++ \\
+++ \\
- \\
- \\
+ \\
+\end{array}$ & $\begin{array}{l}- \\
- \\
- \\
++ \text { to }+++ \\
++ \\
+ \text { to }+++ \\
+ \text { to }+++\end{array}$ & $\begin{array}{l}+++ \\
++ \\
+++ \\
+ \text { to }++ \\
+ \text { to }++ \\
+ \text { to }++ \\
+ \text { to }++\end{array}$ & $\begin{array}{l}+ \\
++ \\
- \text { to }+ \\
+++ \\
+++ \\
+++ \\
+++\end{array}$ \\
\hline
\end{tabular}

- absent, + mild,++ moderate,+++ severe. Other abbreviations as in Table I.

Figure 3: Light chain protein (AL) amyloidosis (case 1). Section of jejunum showing extensive amyloid deposits in the muscularis propria and muscle tissue replaced by amyloid (top, haematoxylin and eosin (original magnification $\times 45$ ); bottom Congo red stain with polarised light (original magnification $\times 50)$ ).
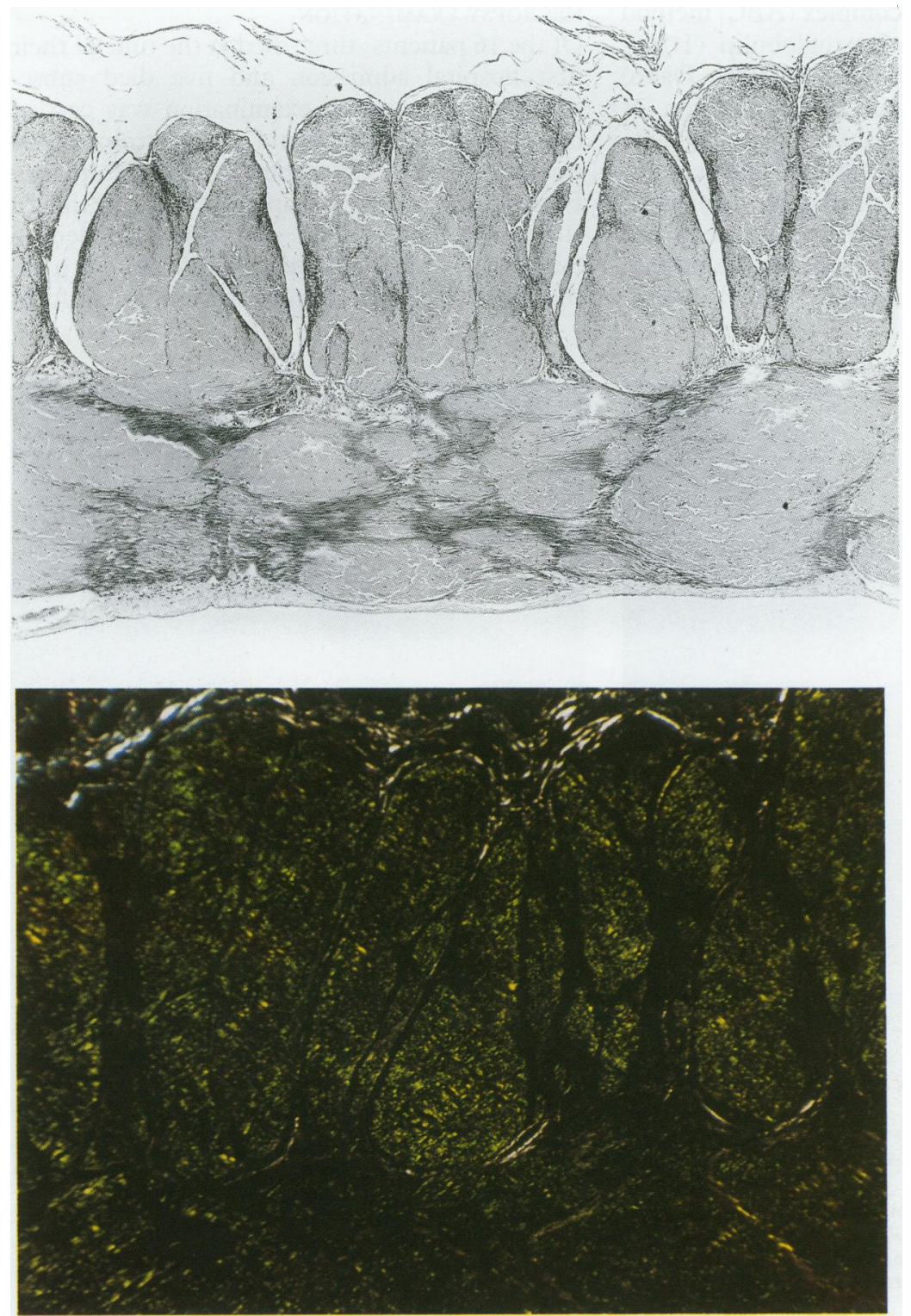

myenteric plexuses, and blood vessels was graded from - to +++ : - , absent; + , mild; ++ , moderate; +++ , severe. The smooth muscle replacement and degeneration or reduction of the myenteric plexuses were also graded from - to +++

\section{Results}

CHEMICAL TYPES OF AMYLOID PROTEIN

According to the results of immunohistochemistry and sensitivity to $\mathrm{KMnO}_{4}$ reaction, there were 13 patients with AA amyloidosis, two with $\mathrm{AL}$, and one with $\mathrm{AH}$. Good correlation was noted between clinical classification and the expected amyloid type in 15 of 16 patients; the 12 patients with secondary amyloidosis had AA, two with multiple myeloma had $\mathrm{AL}$, one with longterm haemodialysis had AH. An exceptional case, who was clinically classified as primary amyloidosis because no predisposing disease could be recognised, showed deposits of AA protein as evidenced by a positive stain for antiAA antibody, which was sensitive to $\mathrm{KMnO}_{4}$ reaction.

\section{CLINICAL FEATURES}

All 16 patients suffered from similar symptoms such as nausea, vomiting, abdominal distension, and pain. The patients had either diarrhoea or constipation. Malnutrition was evident in all patients whose laboratory data showed hypoalbuminaemia (mean (SD) was $2.6(0.6) \mathrm{mg} / \mathrm{dl}$, ranging from 1.0 to $3.5 \mathrm{mg} / \mathrm{dl}$ ). The duration of obstructive symptoms varied widely with a range from a few weeks to several years. Thirteen had an acute or subacute self limiting condition, but the remaining three had several years history of recurrent obstructive symptoms. Table I summarises the clinical features and chemical types of amyloid protein.

We found differences in the clinical signs between amyloid types. The patients with AL and $\mathrm{AH}$ presented with chronic, intermittent, obstructive symptoms, which developed into a severe form that required admission to hospital. The patients with AA had no chronic obstructive symptoms until they developed an acute condition with apparent intestinal obstruction. In all patients, plain films of the abdomen showed abnormal gastrointestinal gas. Considerable gaseous dilatation of the small and large bowel was consistently seen in the $\mathrm{AL}$ and the $\mathrm{AH}$ patients during their hospital stay (Fig 1), whereas the abnormal gas disappeared after treatment in 12 of 13 patients with AA (Fig 2).

All patients received total parenteral nutrition treatment. The daily maintenance dose of calories was 2000 to $2400 \mathrm{kcal}(40-60 \mathrm{kcal} / \mathrm{kg}$ body weight). The average period of treatment was $10.3(6 \cdot 7)$ weeks, ranging from 2 to 28 weeks. One patient with AA died shortly after the start of total parenteral nutrition because of renal failure and sepsis. In 12 patients, all of whom were AA, total parenteral nutrition was effective in improving symptoms and signs, and thereafter, made it possible to maintain adequate oral intake again. In these AA patients, there was 
Figure 4: $A H$ amyloidosis (case 3). Fejunal specimens showing massive amyloid deposits in the muscularis propria and slight deposits in the submucosal vessels (arrow) (left, Congo red stain, right, avidin-biotin complex method with anti$\beta_{2}$-microglobulin antibody (brown reaction product) original magnification $\times 80$ ).

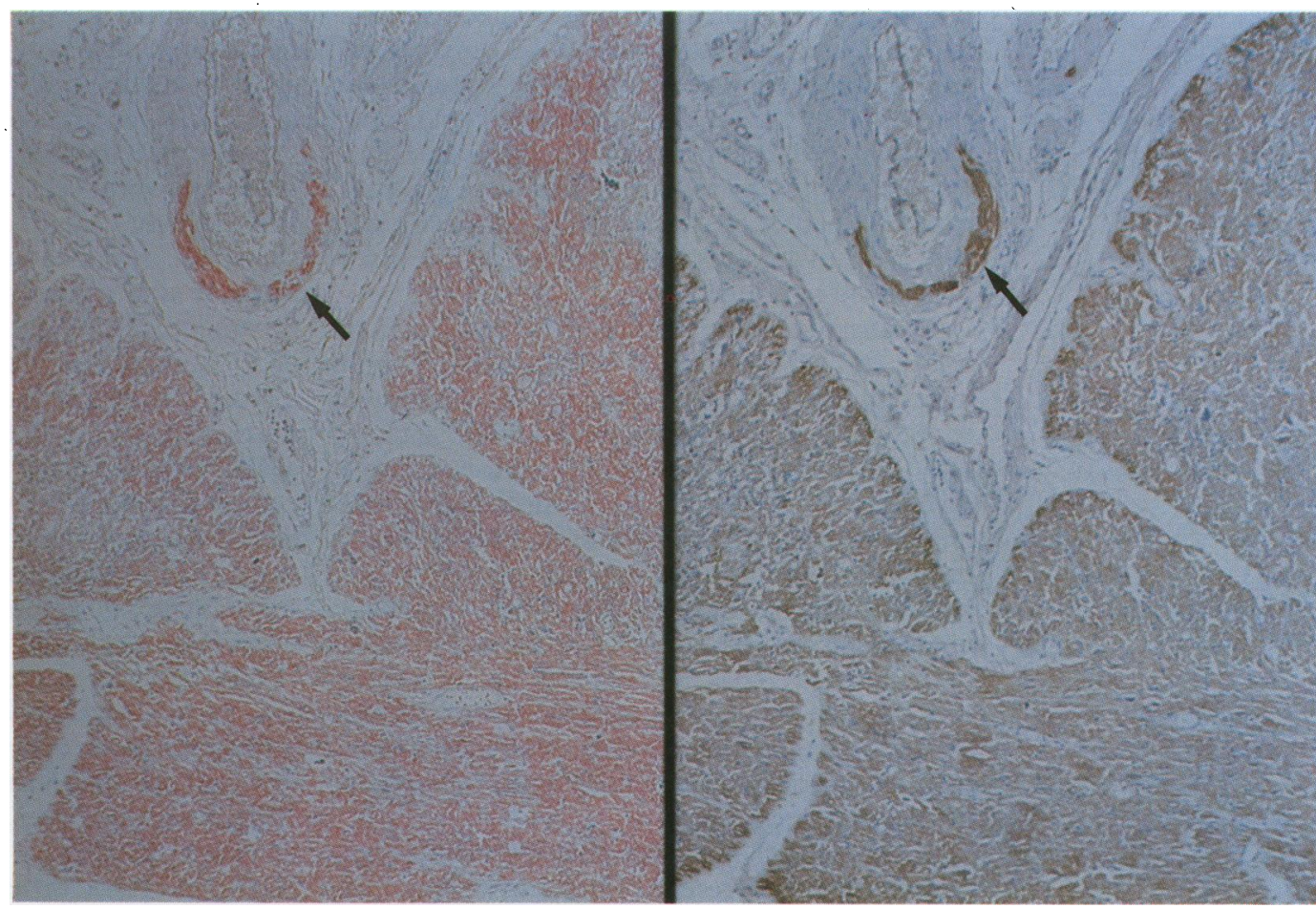

no recurrence of paralytic ileus or severe obstructive symptoms during the follow up ranging from 1.9 to 10.6 years (average $5 \cdot 1$ years), although minor symptoms occasionally occurred. In the remaining three patients $(A L$ in two and $\mathrm{AH}$ in one), however, the obstructive symptoms were persistent and quite resistant to total parenteral nutrition treatment. Medical treatments such as cholinergic agents, metoclopramide, and cisapride were also ineffective. All of them eventually died of cardiac failure without the return to normal bowel function.

\section{NECROPSY FINDINGS}

In all seven necropsy cases, amyloid was found in every site of the gastrointestinal tract including the oesophagus, stomach, small, and large intestines. Table II shows the degree of amyloid deposition and destruction of organic structures in the muscularis propria, myenteric plexuses, deposits in Auerbach's plexus. The nerve bundles and ganglion cells are compressed by amyloid and show atrophic changes (haematoxylin and eosin stain original magnification $\times 350$ ).

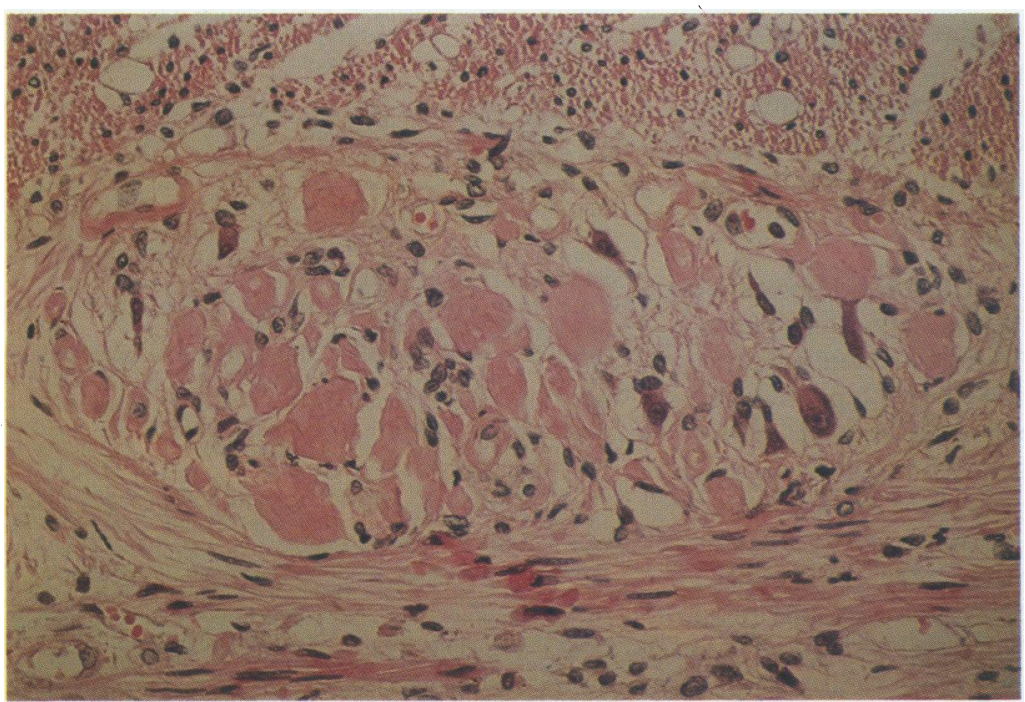

and blood vessels of the small intestine. In comparing the $\mathrm{AA}, \mathrm{AL}$, and $\mathrm{AH}$ cases, we found an appreciable difference in the degree of amyloid deposits in the muscularis propria. By contrast with negative or slight smooth muscle infiltration in the AA cases, the muscularis was quite extensively affected in the AL (Fig 3) and the AH cases (Fig 4). In cases with massive deposits, there were degenerative changes in muscle fibres, with muscle tissue being replaced by amyloid.

Amyloid was found in the myenteric plexuses in the AA cases (Fig 5). The degree of amyloid deposition in the myenteric plexuses varied widely; some were free of amyloid in certain areas, while massive amyloid deposits were evident in others. In plexuses with amyloid deposits, some residual ganglion cells showed degenerative changes. In the AL and $\mathrm{AH}$ cases, we could not find any amyloid in the myenteric plexuses. Many Auerbach's plexuses were compressed, however, by the surrounding abundant amyloid deposits, with a diminution in their number and the presence of degenerative ganglion cells.

In all cases, vascular deposits of amyloid were found most commonly in the submucosa. Massive vascular deposits were found in the AA cases, while the degree was moderate in the $\mathrm{AL}$ and slight in the AH.

These histological findings were similar in all parts of the gastrointestinal tract. The degree of amyloid deposition, however, was greatest in the small intestine.

\section{Discussion}

The main finding of this study is that if intestinal pseudo-obstruction develops in patients with amyloidosis, the clinical features are considerably different according to the chemical types of amyloid protein. Acute or subacute self limiting 
intestinal pseudo-obstruction (so called paralytic ileus) occurred in patients with AA amyloidosis and bowel function was usually restored by conservative treatment. Conversely, chronic intestinal pseudo-obstruction, which is manifested clinically by recurrent attacks of obstructive conditions, occurred in the patients with $\mathrm{AL}$ and $\mathrm{AH}$ amyloidosis, with failure of intestinal propulsion to return.

Abnormalities of gastrointestinal motility may occur in all forms of amyloidosis ${ }^{120}$ and intestinal pseudo-obstruction has been reported in secondary ${ }^{712}$ or primary amyloidosis, ${ }^{10}$ including amyloidosis associated with multiple myeloma. ${ }^{6-8}$ Although the mechanisms of impaired motility have not been fully defined, infiltration of intestinal smooth muscle ${ }^{6-8}$ and gastrointestinal neuropathy with amyloid involvement of the autonomic nerves ${ }^{20-22}$ have been reported. It has not be concluded, however, which of the two factors dominantly affects the bowel motor function, and the relation between motility disorders and chemical types of amyloid has not been examined.

In this study, the most striking histological finding was the presence of extensive amyloid infiltration of the smooth muscle in the $\mathrm{AL}$ and the AH cases, but such amyloid deposits were not seen in the AA cases. If the amyloid almost totally replaces smooth muscle, intestinal propulsive activity disappears. ${ }^{78}$ Once massive amyloid deposits occur in the muscularis propria, this myopathy is thought to be an irreversible change because of the difficulty of elimination of this insoluble protein. This may also explain the finding that the $\mathrm{AL}$ and the $\mathrm{AH}$ cases in this study did not respond to any treatment and had a poor prognosis when they presented with severe intestinal obstruction. The possibility exists, however, that some treatments may be effective when the smooth muscle amyloid infiltration is not so extensive, as shown in a case of Fraser $e t a l,{ }^{23}$ which was responsive to cisapride.

Gilat et $a l^{4}$ studied 68 cases of systemic amyloidosis affecting the gastrointestinal tract, and showed that parenchymal deposition predominated in the muscularis propria in primary or myeloma associated amyloidosis, while in secondary amyloidosis it was mainly distributed in the lamina propria mucosa. In reviewing reports on amyloidosis patients with intestinal pseudo-obstruction, the patients with multiple myeloma tend to have extensive smooth muscle infiltration..$^{6-8}$ These studies support our findings that clinically significant amyloid deposits in the muscularis propria are more likely in $\mathrm{AL}$ amyloidosis than in AA.

Recently, a new form of amyloid protein associated with longterm haemodialysis has been identified as $\beta_{2}$-microglobulin. ${ }^{13}$ Gastrointestinal involvement by amyloid has been reported in dialysis patients, and there have been cases of intestinal infarction associated with massive amyloid deposits in the muscle layers of the bowel. ${ }^{1424}$ Although only a few cases have been studied, it seems probable that extensive infiltration and smooth muscle replacement by amyloid deposits occur in patients with $\mathrm{AH}$ amyloidosis, as shown in our case.
Myenteric plexuses often participate in familial amyloid polyneuropathy ${ }^{20}$ and in a few cases with $\mathrm{AL}^{22}$ and $\mathrm{AA} .{ }^{4}$ In this study, pathological examination of the necropsy specimens showed that amyloid deposits in the myenteric plexuses were seen only in the AA cases. Interestingly, 12 of our 13 patients with $\mathrm{AA}$ showed a remarkable improvement in bowel function after receiving total parenteral nutrition treatment. Although total parenteral nutrition does nothing to treat the primary disease directly, it helps the patient receive enough nutrition until bowel functions return to normal again. ${ }^{25}$ Our clinical findings suggest that the neuronal disorder may be compensated to some degree because the intestines are richly innervated. ${ }^{1}$ If the muscularis propria escapes extensive damage, we assume that the impaired bowel propulsion is allowed to recover to some extent. On the other hand, vascular insufficiency might also have contributed to the impaired peristalsis ${ }^{6}$ because appreciable vascular deposits were seen in our AA cases. Further examinations are required, however, to know the exact correlation between them.

In this study, differences in the histological sites of amyloid deposits between the chemical types of amyloid affected the clinical signs of intestinal pseudo-obstruction. Our findings suggest that this disease usually runs a more serious course in AL and AH than in AA. Recent reports show that clinical and histological differences in the preferential sites of amyloid deposition between the chemical types of amyloid exist in the heart, ${ }^{15}$ kidney, ${ }^{26}$ and spleen. ${ }^{27}$ In the heart, clinically significant cardiac amyloid with congestive heart failure is more likely in AL than in AA, because extensive amyloid interstitial infiltration in the myocardium is more often seen in AL than in AA. ${ }^{10} 1215$ In patients with amyloidosis, therefore, we believe that chemical typing of the amyloid protein is very important in predicting the clinical characteristics, course, and prognosis of the disease.

We thank Mr Peter Flaherty for his assistance in preparation of the manuscript.

1 Krishnamurthy S, Schuffler MD. Pathology of neuromuscula disorders of the small intestine and colon. Gastroenterology 1987; 93: 610-39.

2 Schuffler MD, Rohrmann CA, Chaffee RG, Brand DL, Delaney $\mathrm{JH}$, Young $\mathrm{JH}$. Chronic intestinal pseudoobstruction: a report of 27 cases and review of the literature. Medicine 1981; 60: 173-96.

3 Morson BC. Morson E' Dawson's gastrointestinal pathology. 3rd ed Oxford: Blackwell Scientific Publications, 1990: 234-9.

Gilat T, Revach M, Sohar E. Deposition of amyloid in the gastrointestinal tract. Gut 1969; 10: 98-104.

5 Tada $S$, Iida $M$, Iwashita A, Matsui T, Fuchigami T, Yamamoto T, et al. Endoscopic and biopsy findings of the upper digestive tract in patients with amyloidosis Gastrointest Endosc 1990; 36: 10-4.

6 Gilat T, Spiro HM. Amyloidosis and the gut. Am $\mathcal{F}$ Dig Dis 1968; 13: 619-33.

7 Legge DA, Wollaeger EE, Carlson HC. Intestinal pseudoobstruction in systemic amyloidosis. Gut 1970; 11: 764-7.

Wald A, Kichler J, Mendelow H. Amyloidosis and chronic intestinal pseudoobstruction. Dig Dis Sci 1981; 26: 462-5. Glenner GG. Amyloid deposits and amyloidosis. $N E n g l f M e d$ 1980; 302: 1283-92, 1333-43.

10 Kyle RA, Greipp PR. Amyloidosis (AL): clinical and laboratory features in 229 cases. Mayo Clin Proc 1983; 58. 665-83.

tory features in 2 cases. Mayo Clin Proc 1983; 58:665-83. Levin M, Franklin EC, Frangione B, Pars $M$. The amin sequence of a major noninmmunoglobulin compo
some amyloid fibrils. $\mathcal{f}$ Clin Invest 1972; 51: 2773-6.

12 Gertz MA, Kyle RA. Secondary systemic amyloidosis:

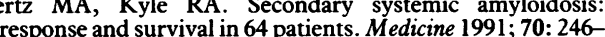
56.

13 Gejyo F, Yamada T, Odani S, Nakagawa Y, Arakawa M, 
Kunitomo T, et al. A new form of amyloid protein associated with chronic hemodialysis was identified as $\beta_{2}$-microglobulin. Biochem Biophys Res

14 Fuchs A, Jagirdar J, Schwartz IS. Beta 2-microglobulin amyloidosis (AB2M) in patients undergoing long-term hemodialysis: a new type of amyloid. Am $\mathcal{F}$ Clin Pathol 1987; 88: $302-7$.

15 Wright JR, Calkins E. Clinical-pathlogic differentiation of common amyloid syndromes. Medicine $1981 ; 60: 429-48$.

16 Iida $M$, Yamamoto T, Yao T, Fuchigami T, Fujishima $M$. Jejunal endoscopy using a long duodenofiberscope

17 Kitamoto T, Ogomori K, Tateishi J, Prusiner SB. Formic and pretreatment enhances immunostaining of cerebral and pretreatment enhances immunostaining of

18 Wright JR, Calkins E, Humphrey RL. Potassium permanganate reaction in amyloidosis: A histologic method permanganate reaction in amyloidosis: A histologic method to assist in differe

19 Matsumoto T, Iida M, Hirakawa M, Hirakawa K, Kuroki F, Lee $S$, et al. Breath hydrogen test using water-diluted lactulose in patients with gastrointestinal amyloidosis. Dig Dis Sci 1991; 36: 1756-60.

20 Ikeda S, Makishita H, Oguchi K, Tanagisawa N, Nagata T. Gastrointestinal amyloid deposition in familial amyloid polyneuropathy Neulorogy 1982; 32: 1364-8.

21 Battle WM, Rubin MR, Cohen S, Snape WJ Jr. Gastrointestinal-motility dysfunction in amyloidosis. $N$ Englf Med

22 Brody IA, Wertlake PT, Laster L. Causes of intestinal symptoms in primary amyloidosis. Arch Intern Med 1964; 113: 512-8

23 Fraser AG, Arthur JF, Hamilton I. Intestinal pseudoobstruction secondary to amyloidsis responsive to cisapride. Dig Dis Sci 1991; 36: 532-5.

24 Choi HH, Heller D, Picken MM, Sidhu GS, Kahn T. Infarction of intestine with massive amyloid deposition in two patients on long-term hemodialysis. Gastrointerology 1989; 96: $230-4$.

25 Faulk DL, Anuras S, Freeman JB. Idiopathic chronic intestinal pseudo-obstruction: Use of central venous intestinal pseudo-obstruction: Use

26 Shiiki H, Shimokama T, Yoshikawa Y, Toyoshima H, Kitamoto T, Watanabe T. Renal amyloidosis: correlations between morphology, chemical types of amyloid protein and clinical features. Virchows Arch [A] 1988; 412: 197-204.

27 Ohyama T, Shimokawa T, Yoshikawa Y, Watanabe T Splenic amyloidosis: correlations between chemical types of amyloid protein and morphological features. Mod Pathol 1990; 3: 419-22. 